\title{
WATER SAVING AND YIELD INCREASE OF SUGAR BEET WITH SUBSURFACE DRIP IRRIGATION
}

\author{
M. SAKELLARIOU-MAKRANTONAKI 1 ,* \\ D. KALFOUNTZOS ${ }^{2}$ \\ P. VYRLAS ${ }^{1}$
}

\author{
1 University of Thessaly \\ Department of Agriculture \\ Crop Production and Rural Environment \\ Agricultural Hydraulics Laboratory \\ Fytoko, 38446 Nea Ionia Magnesias, Greece \\ 2 National Agricultural Research Foundation \\ Institute of Soil Classification and Mapping \\ Theofrastou 1, 41335 Larissa, Greece \\ * to whom all correspondence should be addressed \\ tel: +30-24210-93059; fax: +30-24210-93059, 74
}

\begin{abstract}
This study was conducted to evaluate the surface and subsurface drip irrigation (SDI) application effects on sugar beet crop performance, under two levels (100\% and 80\%) of water application depth. The experimental design was a split plot with four replications. Laterals were set every second crop row ( $1 \mathrm{~m}$ apart), with emitters spaced $1 \mathrm{~m}$ apart. In the case of SDI, laterals were buried $0.45 \mathrm{~m}$ under the ground. Soil moisture measurements were taken up to $75 \mathrm{~cm}$ depth, using the TDR method. The soil water content and the yield characteristics of each treatment were recorded. Irrigation method showed to affect crop performance significantly while water application level was less critical. The experimental results indicated that the subsurface drip irrigation leaded to a greater yield and higher sugar content making significant water saving compared to surface drip irrigation.
\end{abstract}

KEYWORDS: irrigation water management, drip systems, sugar beet, yield, sugar content.

\section{INTRODUCTION}

Subsurface drip irrigation (SDI) is a variation of the conventional surface drip irrigation. The laterals are buried in a depth below the soil surface depending mostly on the tillage practices and the crop to be irrigated. Subsurface drip irrigation is probably the oldest modern irrigation method. Phene et al. $(1983,1993)$ report that in USA, at 1913, House irrigated apple trees, alfalfa and cereal crops with subsurface porous pipes and reported that the method was quite expensive for ordinary farm crops and recommended its use only for intensive crops.

As Phene et al. (1993) report, Korneff at 1926 suggested the use of a closed, automated subsurface irrigation system consisted of porous pipes connected through a manifold to a reservoir under a small vacuum. As water was removed from the soil by the crop a potential gradient developed, which pulled water from the reservoir 
until equilibrium was restored. Bordas and Mathieu, at 1930-31, applied Korneff's method and reported increased yield as well as significant water and fertilizer conservation.

Despite the above, several problems restricted the widespread adoption of the method. Goldberg et al., as Phene et al. (1993) reported, outlined the following problems:

- Inspection of a subsurface system is very difficult.

- Emitters' clogging by roots and solids may cause poor system performance.

- A subsurface system is difficult to be repaired and maintained.

Phene et al. (1983), suggested management techniques which could be used successfully to prevent clogging and make SDI more feasible. The development of improved plastic materials has made SDI less costly and adaptable for many crops including cotton (Smith et al., 1991). Solomon (1993) reports that when using SDI, irrigation water and injected chemicals, like fertilizers, are supplied directly to the roots. This is a special advantage for nutrients that have low mobility into the soil. In SDI the top $15-20 \mathrm{~cm}$ of soil, have lower moisture when the laterals are buried in $45 \mathrm{~cm}$ depth, resulting to reduced evaporation (Phene et al., 1983; Solomon, 1993). A relatively dry soil surface permits farm equipment access and movement during the whole irrigation period and eliminates weed growth (Schwankl et al., 1990). In addition, restricts root rot and other soil diseases and prevents crust creation that inhibits soil aeration and rainwater insertion into the soil causing surface run-off. Except the above, a subsurface irrigation system is not exposed to sun and extreme weather conditions that means longer material life. The most basic of all the advantages is that permanent installation below the plough depth, provides labour savings the cost of which is quite high in developed countries.

Shani et al. (1996) from the experiments they conducted in Israel, proved that the rate of water which is discharged from SDI emitters must be controlled according to the soil hydraulic conductivity. Ruskin (2000) reports that SDI could be applied in small frequent amounts, hence in medium and heavy textured soils the water movement into the soil is mainly due to capillary forces. So applying the same water amount, a $46 \%$ water saving can be achieved using SDI.
Sugar beet is one of the most tolerant crops to drought and to soil salinity due to the long growing period, which does not present sensitivity during blossom and to the deep rooting system and its ability to get used to osmotic pressure variation (Dunham, 1993). Generally, the sugar content increases in conditions of limited water availability while the opposite occurs with the dry mass. Amaducci et al. (1989), studied the sugar beet yield response to irrigation in Southern and Northern Italy. According to their study, irrigation decreased the sugar content and increased the root mass resulting to the increase of the total sugar yield.

Drip irrigation of sugar beet is continuing to be under study in Greece (Sakellariou -Makrantonaki et al., 1998, 1999, 2000). Subsurface drip has not been applied in Greece yet, although in many countries, where irrigation water is in shortage, has progressed from being a novelty employed by researchers, to an accepted method of irrigation. Since irrigation water shortage becomes more perceptible in Greece, the use of water must be improved in irrigated agriculture and must seek alternative methods such as SDI.

The aim of this experiment was to study the soil moisture distribution, sugar beet yield, the root weight and the sugar content, under two levels of water application depth and different irrigation design.

\section{MATERIALS AND METHODS}

\section{Field experiment layout}

The surface system and the SDI were installed in an experimental field of $1980 \mathrm{~m}^{2}$ at the University Farm, $20 \mathrm{~km}$ west of the city of Volos, Greece (Long. $22^{\circ} 45^{\prime}$, Lat. $39^{\circ} 23^{\prime}$ ). The experimental design was laid out in split plot design with four replications. The treatments consisted of two drip lateral placements (surface and subsurface) as main treatment and two irrigation levels as subtreatments $(100 \%$ and $80 \%$ of the irrigation depth). Each experimental block was $4 \mathrm{~m}$ in width (across the crop rows) and $30 \mathrm{~m}$ in length (along the crop rows). The subsurface laterals were buried at a depth of $0.45 \mathrm{~m}$. Sugar beet (Beta vulgaris $L$., var. Rizor) was seeded with seed drill on April 7, 1999 at a row spacing of $0.5 \mathrm{~m}$ and in-row spacing of $0.12 \mathrm{~m}$. Two light irrigations were applied after seeding for the establishment of seedlings using sprinkle laterals equipped with 


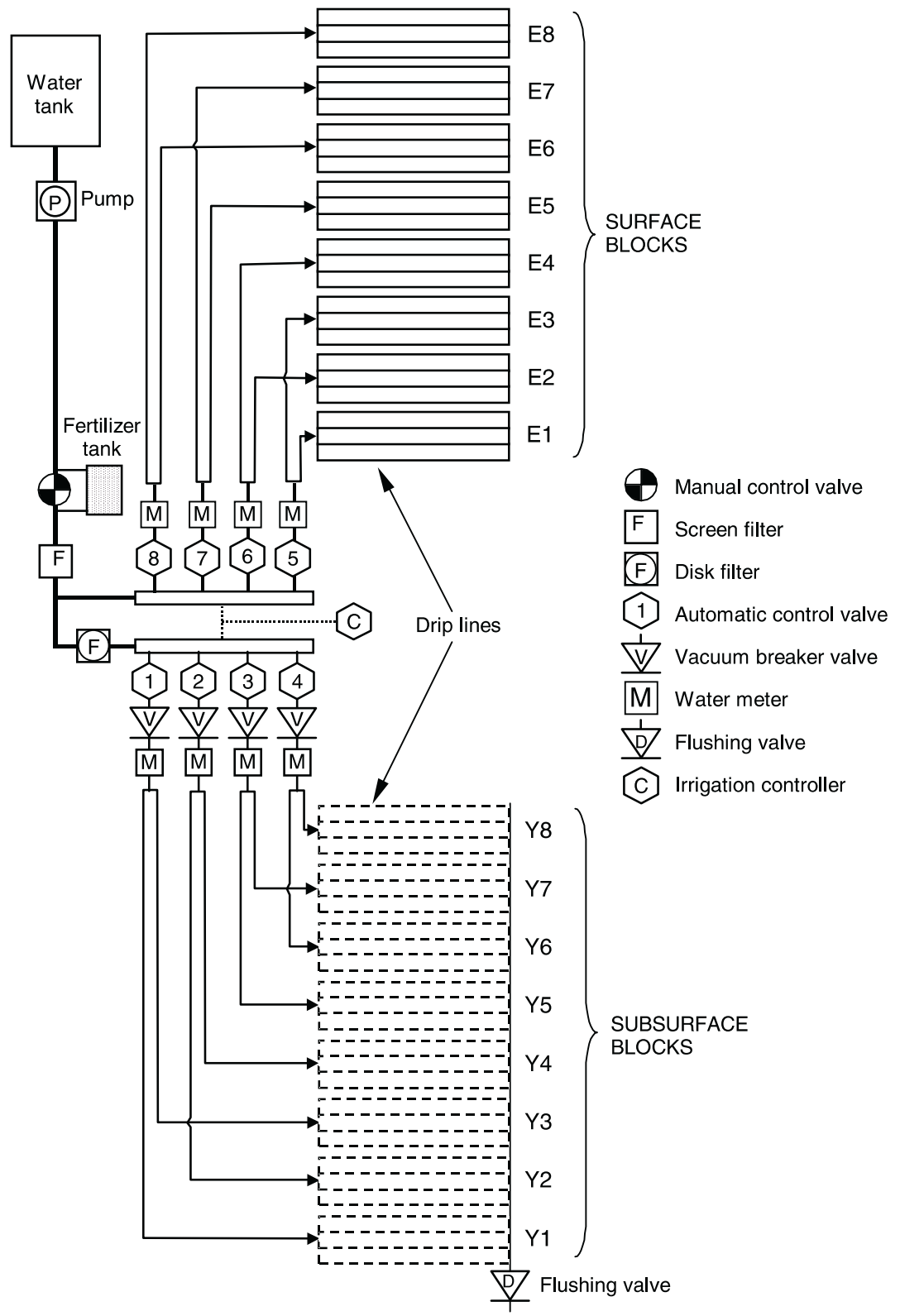

Figure 1. Graphic representation of the experimental field (not in scale)

small impact sprinklers. Hand weeding was carried out three times during the growing season. The crop was harvested on September 8, 1999. Top and root yields were separated and weighed. The root sugar content was determined in samples from each plot by a refractometer procedure. The irrigation network consisted of a main delivery pipe $(\mathrm{PE}, 32 \mathrm{~mm})$ and the secondary ones (PE, $25 \mathrm{~mm}$ ). The drip laterals of both the surface and subsurface systems were of $17-\mathrm{mm}$ diameter polyethylene pipe with in-line RAM self-regulated emitters manufactured by Netafim, spaced 1 meter apart. The discharge rate of the emitter was 3 litres per hour at $150 \mathrm{kPa}$ pressure after testing according to I.S.O. Standards (ISO S9261, 1991). Between the main pipe and the laterals and after the screen filter, two collectors were fitted, one for the surface and one for the subsurface system respectively. The surface system collector included four automatic control valves with four water meters, connected to two pipes, which fed two experimental blocks. Four drip laterals irrigated each block.

The subsurface system collector included four vac- 
Table 1. Physical and chemical soil properties

\begin{tabular}{|c|c|c|c|c|c|}
\hline $\begin{array}{c}\text { Depth } \\
(\mathbf{c m})\end{array}$ & $\begin{array}{c}\text { Soil } \\
\text { type }\end{array}$ & $\begin{array}{c}\text { Bulk density } \\
\left(\mathbf{g ~ c m}^{-3}\right)\end{array}$ & $\begin{array}{c}\text { Field Capacity } \\
(\mathbf{\%} \mathbf{~ w})\end{array}$ & $\begin{array}{c}\text { Wilting Point } \\
(\mathbf{\%} \mathbf{w})\end{array}$ & $\begin{array}{c}\text { Ks } \\
\left(\mathbf{c m ~ h} \mathbf{h}^{-\mathbf{1}}\right)\end{array}$ \\
\hline $0-20$ & L & 1.25 & 20.9 & 11.48 & 4.86 \\
\hline $20-40$ & CL & 1.23 & 21.2 & 11.64 & 0.49 \\
\hline $40-60$ & CL & 1.21 & 21.5 & 11.81 & 4.89 \\
\hline
\end{tabular}

uum breaker valves to prevent any water suction and consequently emitter clogging when irrigation pauses and also a disk filter enriched with Trifluralin which was injected during irrigation for preventing root intrusion. The ends of the laterals were joined in a $25-\mathrm{mm}$ diameter manifold, ending in turn in a flushing valve. The automatic control valves were connected to an irrigation controller making irrigation automated. A graphic representation of the experimental field is given in Figure 1. The amount of water applied per irrigation was determined by using a type A evaporation pan. The cumulative evapotranspiration of the previous day was used to calculate the irrigation amounts to replenish water used by the crop. During the irrigation period 13 irrigation events were conducted. The $100 \%$ of irrigation depth treatment resulted in a 444-mm water depth, while the treatments designed to receive the $80 \%$ of the irrigation depth, consumed $370 \mathrm{~mm}$ of water (as measured by the water meters), thus the $83,3 \%$ of the total irrigation amount. Rain is included in the above irrigation depths. Besides, a total irrigation amount of $20 \mathrm{~mm}$ was applied for crop establishment. Henceforth, for convenience reasons, the irrigation amounts will be signed as $100 \%$ and $80 \%$ treatments.

Soil moisture measurements were taken the first day after irrigation, at the middle of the laterals and the middle of the crop rows in both the treatments.

\section{Soil moisture monitoring}

Soil water content monitoring and measurement was done using Time Domain Reflectometry (TDR) instrumentation (ESI model manufactured by Soil Moisture Corp.), (Sakellariou Makrantonaki et al., 1997). TDR is a non-radioactive method, fast and independent of soil type (except extreme cases of soils), the working principle of which is based on the direct measurement of the dielectric constant of soil and its conversion to water volume content (Topp and Davis, 1985;
Zegelin et al., 1992). Measurements were correlated to soil depth with respect to emitter location. Hydraulic conductivity was measured by a Guelph permeameter, while conventional methods were implemented for soil analysis.

\section{RESULTS AND DISCUSSION}

According to soil analyses and taxonomy done by Institute of Soil Classification and Mapping, soil is a loam belonging to Typic Xerofluvent subgroup of Entisols. Hydraulic conductivity and other physical and chemical soil properties are presented in Table 1.

The low value of hydraulic conductivity at $20-40$ $\mathrm{cm}$ denoted that there was a compacted layer due to tillage. In order to disrupt that layer a deep ploughing was performed during autumn.

\section{Soil moisture}

Soil moisture distribution before and after irrigation under the different irrigation amounts, for the subsurface and the surface systems, are shown in Figures 2 and 3 respectively.

The graphs show that $15 \mathrm{~cm}$ below the soil surface in the SDI blocks is dry so no evaporation occurs in comparison to surface irrigation blocks.

The soil moisture at the depth of $30-60 \mathrm{~cm}$ was higher in SDI blocks. The latter is considered as a quite beneficial fact for the plant, which develops the $2 / 3$ of its roots beyond $30 \mathrm{~cm}$ depth. Soil moisture values at the same depth in surface system were lower than the field capacity.

\section{Yield}

In general, root yield was higher under subsurface drip irrigation. The $80 \%$ and $100 \%$ SDI treatments produced a similar root yield, but the first saved $16.6 \%$ irrigation water. Also, $83.3 \%$ of applied water may produce $22.2 \%$ more yield if water is applied as SDI rather than surface drip. Furthermore, there was a little difference in sugar content between the $100 \%$ and $80 \%$ SDI treatments while sugar content values were not signif- 

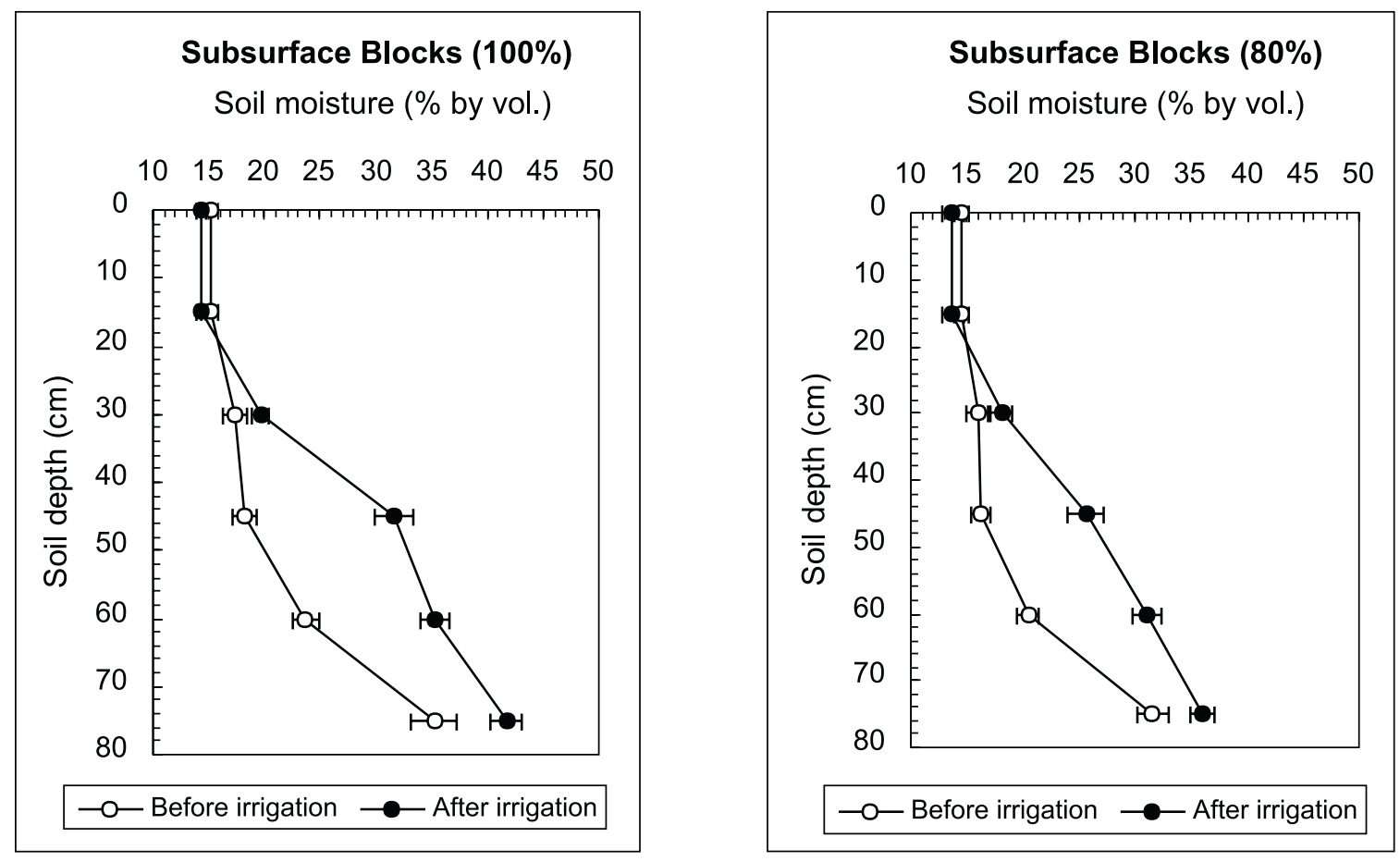

Figure 2. Soil moisture distribution in subsurface system blocks under $100 \%$ and $80 \%$ water application before and after irrigation on July 19, 1999.
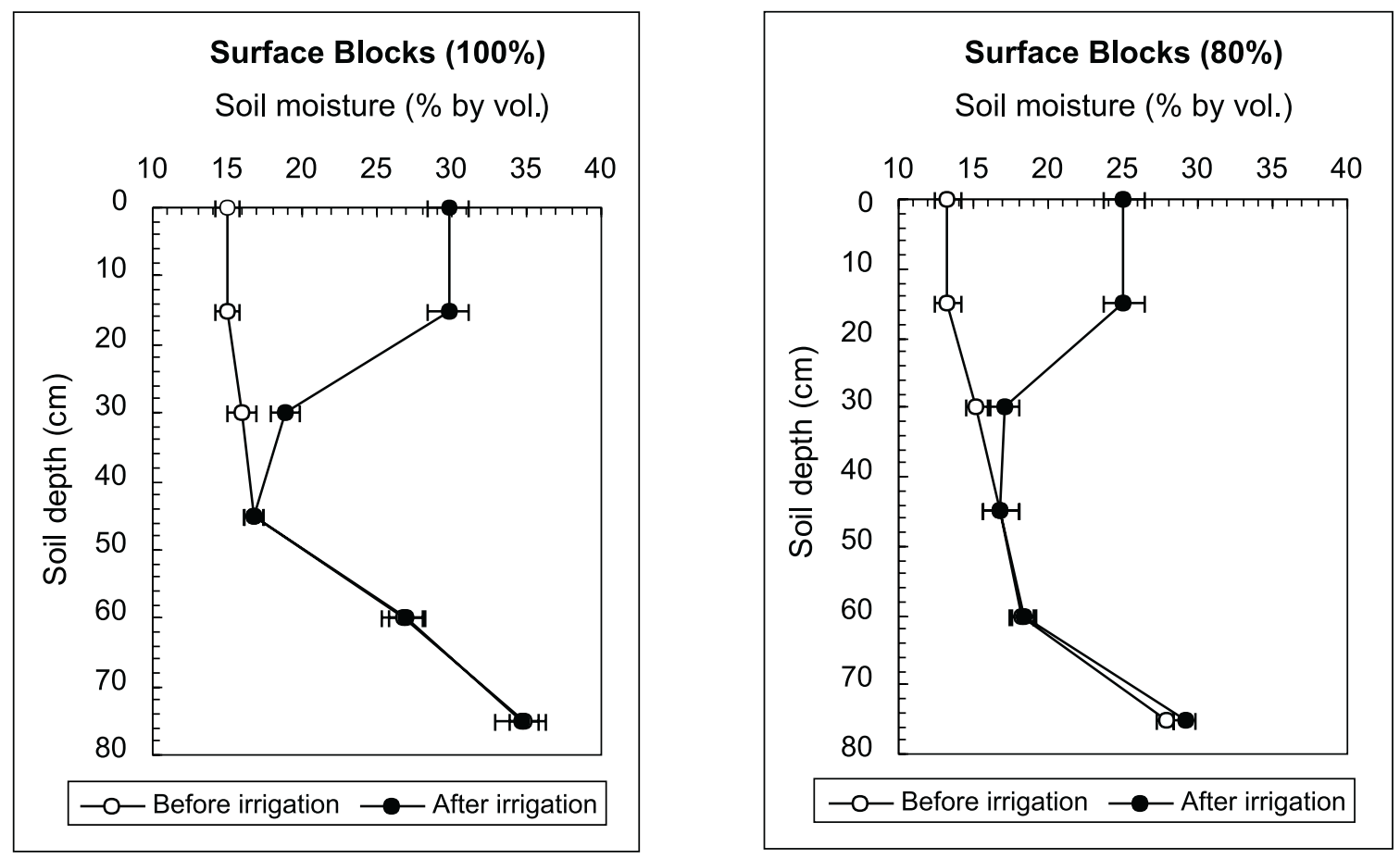

Figure 3. Soil moisture distribution in surface system blocks under $100 \%$ and $80 \%$ water application before and after irrigation on July 19, 1999. 
Table 2. Statistical analysis for root yield and sugar content (LSD test)

\begin{tabular}{|cccccc|}
\hline & & \multicolumn{3}{c|}{ Treatment } \\
\cline { 3 - 6 } Parameter & Significance level & $\begin{array}{c}\text { Subsurface drip } \\
\mathbf{1 0 0 \%}\end{array}$ & $\begin{array}{c}\text { Subsurface drip } \\
\mathbf{8 0 \%}\end{array}$ & $\begin{array}{c}\text { Surface drip } \\
\mathbf{1 0 0 \%}\end{array}$ & $\begin{array}{c}\text { Surface drip } \\
\mathbf{8 0 \%}\end{array}$ \\
\hline $\begin{array}{c}\text { Root weight, } \\
\left(\text { ton ha } \mathbf{~ h}^{-1}\right)\end{array}$ & $0.0147\left(^{*}\right)$ & $68.87 \mathrm{c}$ & $66.69 \mathrm{bc}$ & $60.31 \mathrm{ab}$ & $54.58 \mathrm{a}$ \\
\hline $\begin{array}{c}\text { Sugar content, } \\
(\text { Pol) }\end{array}$ & $0.0339\left(^{*}\right)$ & $14.025 \mathrm{~b}$ & $13.13 \mathrm{a}$ & $12.87 \mathrm{a}$ & $12.90 \mathrm{a}$ \\
\hline
\end{tabular}

(*): $\mathrm{P}<0.05$

Table 3. Gross income for each treatment for year 1999

\begin{tabular}{|lccccc|}
\hline \multicolumn{2}{|c}{ Treatments } & $\begin{array}{c}\text { Root yield } \\
\left(\text { ton ha } \mathbf{~}^{-\mathbf{1}}\right)\end{array}$ & $\begin{array}{c}\text { Sugar content } \\
(\text { Pol })\end{array}$ & $\begin{array}{c}\text { Value } \\
(\text { Euro ton }\end{array}$ & $\begin{array}{c}\text { Gross income } \\
\left(\text { Euro ha }^{-\mathbf{1}}\right)\end{array}$ \\
\hline [1] Subsurface drip & $\mathbf{1 0 0 \%}$ & 68.87 & 14.02 & 42.65 & 2937.30 \\
\hline [2] Subsurface drip & $\mathbf{8 0 \%}$ & 66.69 & 13.13 & 36.41 & 2428.20 \\
\hline [3] Surface drip & $\mathbf{1 0 0 \%}$ & 60.31 & 12.87 & 34.68 & 2091.55 \\
\hline [4] Surface drip & $\mathbf{8 0 \%}$ & 54.58 & 12.90 & 35.02 & 1911.39 \\
\hline
\end{tabular}

icantly different between $100 \%$ and $80 \%$ surface drip.

The statistical analysis results are presented in Table 2.

After the financial elaboration of yield parameters, the potential gross income per hectare for each treatment for the year 1999 was calculated and is presented in Table 3. The value of root weight depends on sugar content and the calculations are based on the price-table of Hellenic Sugar Industry for year 1999. The results show that in $100 \%$ treatments, SDI gave an additional benefit of 845.75 Euro ha $^{-1}$ in relation with surface drip, while in $80 \%$ treatments, SDI exceeded surface drip by 516.81 Euro ha $^{-1}$.

\section{CONCLUSIONS}

Experiments conducted in a sugar beet experimental field showed that soil moisture was increased by depth when subsurface drip irrigation was used. The overall performance of the two irrigation systems showed that root yield and sugar content were higher for sugar beets grown under subsurface drip irrigation rather than surface drip. This could be a quite encouraging consideration for using SDI, since the financial benefit that arises combining higher yield and sugar content, is significantly greater compared to surface drip.

Also, results obtained after statistical elaboration of experimental data, indicate that under SDI, applying the $80 \%$ of the design irrigation depth, a significant water saving could be achieved without significant yield reduction.

The profitability of SDI at this site is certain. Further experimentation and field research need to be done in order to bring into general use the conclusions that have been gathered up to now.

\section{REFERENCES}

Amaducci, M.T., Cucci, G., De Caro, A., Gherbin, P., Mambelli, S. and Venturi, G. (1989), Sugar Beet Yield Response to Irrigation in Different Environmental Conditions, Irrigatione E Drainaggio, 36, 153-159.

Dunham, R.M. (1993), The Sugar Beet Crop: Science in to Practice, Cooke, D.A and Scott R.K. (eds), Chapman \& Hall.

ISO S9261 (1991), Agricultural Irrigation Equipment - Emitting Pipe Systems - Specifications and test methods, International Organization for Standardization.

Phene, C.J., Blume, M.F., Hile, M.M.S., Meek, D.W. and Re, J.V. (1983), Management of Subsurface Trickle Irrigation Systems. ASAE paper No. 83-2598. 
Phene, C.J., Hutmacher, R.B. and Ayars, J.E. (1993), Subsurface Drip Irrigation: Realizing the Full Potential. In: Proc. of workshop "Subsurface Drip Irrigation, Theory, Practices and Application", February 2, Visalia, California, 97-117.

Ruskin, R. (2000), Subsurface Drip Irrigation and Yields, www.geoflow.com.

Sakellariou - Makrantonaki, M., Kalfountzos, D. and Papanikos, N. (2000), Evaluation of Surface and Subsurface Drip Irrigation Effect on Sugar-Beet Yield. In: Proc. $2^{\text {th }}$ National Congress of the Hell. Soc. Agric. Eng., (HelAgEng), Volos, 157-164, (In Greek).

Sakellariou - Makrantonaki, M., Tzimopoulos, C. and Kalfountzos, D. (1997), Soil Moisture Measurements Using TDR Method and Statistical Elaboration of Data. In: Proc. $7^{\text {th }}$ National Congress of the Hell. Hydr. Soc., E.Y.E., Patras, 184-192, (In Greek).

Sakellariou - Makrantonaki, M., Maslaris, N., Kalfountzos, D. and Goulas, C. (1998), Sugar Beet Response to Different Drip Irrigation Arrangements. In: Proc. $1^{\text {st }}$ National Congress, Hell. Soc. of the Agric. Eng., Athens, 271-280, (In Greek).

Sakellariou - Makrantonaki, M., Maslaris, N., Nousios, G., Dioudis, P. and Kalfountzos, D. (1999), Drip Irrigation Design on Sugar Beet Cultivation. In: Proc. $4^{\text {th }}$ National Congress, Hell. Com. Wat. Res. Manag., E.E.D.Y.P., Volos, (In Greek).

Schwankl, L.J., Grattan, S.R. and Miyao, E.M. (1990), Drip irrigation burial depth and seed planting depth effects on tomato germination. In: Proc. $3^{\text {rd }}$ Nat. Irr. Symp., 682-687, ASAE. Phoenix, AZ.

Shani, U., Xue, S., Gordin-Katz, R. and Warrick, A.W. (1996), Soil-limiting from Subsurface Emitters. I: Pressure Measurements, J. of Irrig. and Drain. Eng., ASCE, 122, 291-295.

Smith, R.B., Oster, J.D. and Phene, C.J. (1991), Subsurface Drip Produced Highest Net Return in Westlands Area Study, Calif. Agric., 45, 8-10.

Solomon, K. (1993), Subsurface Drip Irrigation: Product Selection and Performance. In: Subsurface Drip Irrigation: Theory, Practices and Application, Jorgensen, G.S. and Norum K.N. (eds), CATI Publication, No. 921001.

Topp, G.C., and Davis J.L., (1985), Measurement of soil water content using time-domain reflectometry: A field evaluation. Soil Sci. Soc. Am. J., 49, 19-24.

Zegelin, S.J., White, I., and Russel G.F. (1992), A critique of the time domain reflectometry technique for determining field soil-water content. In: Advances in Measurement of Soil Physical Properties: Bringing Theory into Practice, SSSA Special Publication, 30, 187-208. 